\title{
THE REFORM OF SUPERVISORY AuTHORITIES: THE NEW ROLE OF THE BANK OF ITALY
}

\author{
Lucia Quaglia
}

In April 2007, the two largest Italian banks, Unicredito and Capitalia, merged, forming the largest banking group in the Eurozone and signaling a turning point in the configuration of the Italian banking system. The merger was important not only because it involved two of the largest banks, whereas the banking system had long been characterized by the presence of many small banks, but also because it demonstrated the changed approach to banking policy of the Italian central bank, the Bank of Italy. In the past, the Bank's governor, Antonio Fazio (19932005), had blocked the merger of the largest banks. Instead, he had favored the consolidation of small banks with a view to creating Italian banking groups of a sufficiently large size to make them less vulnerable to foreign competition and acquisition. In 2005, the governor's hostility to foreign takeovers and his preference for italianità delle banche, or Italian ownership of banks, made headlines across Europe when he tried to prevent the acquisition of two Italian banks by foreign banking groups. These events gave momentum in 2005-2006 to a major reform of the Italian central bank, which had been in the making since 2001 .

This chapter begins with an evaluation of the governorship of Mario Draghi, who took over from Fazio in 2006. Draghi's stance on the reform of the Bank of Italy, together with Governor Fazio's resignation, made possible a more open and competition-friendly approach

Notes for this chapter begin on page 155 . 
to banking policy in Italy, as well as a reconfiguration of the Bank's governance structure. The research examines the background, causes, and effects of the reform, which must be contextualized within the broader institutional and policy evolution of the central bank.

It is argued that the reform was influenced by external (European) and domestic factors, with bank-specific factors also playing a role. Overall, the main structural driving forces of the reform were external-namely, the establishment of Economic and Monetary Union (EMU) and increased financial market integration in the EU, both of which exerted their influence directly and indirectly. These two EU-wide trends underpinned the activity of transnational banking groups (including the most outward-oriented part of the Italian financial system), the European Commission, and the European Central Bank (ECB), all of which formed a sort of policy coalition in favor of the reform of the Bank of Italy and its approach to banking policy. By contrast, domestic structural factors, including fragmented political institutions and an inward-oriented financial sector, were the main obstacles to the reform. The informal domestic coalition against the reform was composed of a cross-section of political forces-some domestic financial groups and part of the Bank of Italy-that opposed change for a variety of reasons. Bank-specific factors, especially the expertise that the Bank possessed in supervisory matters and its solid institutional reputation (despite the events of 2005), help explain the outcome of the reform, especially the fact that the central bank was able to retain competence for prudential supervision.

\section{The Draghi Governorship So Far}

Before his appointment as governor in December 2005, Draghi had been vice-president and managing director of Goldman Sachs (the international investment bank), based in London, having previously been, in the 1990s, director-general of the Italian Treasury and, before that, executive director of the World Bank. He was thus widely known and highly esteemed abroad, especially in Anglo-Saxon countries, and had first-hand market experience. At the same time, having served as the top civil servant at the Italian Treasury for more than a decade, he was familiar with the machinations of Italian politics and had considerable experience in managing relations between the Bank of Italy and the Ministry of the Economy, a background that is of great benefit at times when the latter relationship is tense.

From the outset, Draghi gave clear signals of change, while emphasizing the continuity of the prestigious tradition of the Bank of Italy. 
Following the new rules agreed upon in 2005, three new members of the Direttorio (Executive Board) were appointed, ${ }^{1}$ whereas one of the vice-deputy governors, Antonio Finocchiaro, who had been appointed in 1997, remained in office. Fabrizio Saccomanni was appointed as director-general, which is the most important position below the governor. Saccomanni, who had been at the Bank of Italy for most of his career, moved back to Rome from London, where he had been vice-president of the European Bank of Reconstruction and Development. He had international experience, having represented the Bank in several international forums, and had been involved in the creation of the single currency. The second vice-deputy governor appointed was Ignazio Visco, who also had considerable international experience. He had been chief economist and director of the Economics Department at the Organisation for Economic Co-operation and Development (OECD), and before and after his experience in Paris, he had held senior positions at the Research Department of the Bank of Italy. The third vice-deputy governor appointed was Giovanni Carosio, who held a senior position at the supervisory department of the Bank of Italy and had international experience, having represented the Bank in several international supervisory forums.

Besides changes at the senior level of management of the Bank of Italy, the approach adopted by the new governor and the Executive Board can be summarized as supporting more openness, accountability, and efficiency. The priority has been to regain "credibility." First, there has been the objective of opening up and modernizing the Italian financial sector. Draghi has been keen to encourage mergers in a banking sector that, aside from Germany's, has been the most fragmented in the EU. He has also made clear that if banks' executives should fail to take the initiative, he would not stand in the way of foreign takeovers. This approach is in marked contrast to that of Fazio, who opposed foreign takeovers while attempting to orchestrate complex domestic alliances. During his 12 years as governor, Fazio, who was criticized for an increasingly autocratic style, personally shaped the entire process of bank mergers in Italy.

After assuming governorship, Draghi permitted two foreign banks, ABN Amro of the Netherlands and BNP Paribas of France, to acquire two medium-sized Italian banks, Antonveneta and Banca Nazionale del Lavoro, while 2006 saw the merger of Banca Intesa with San Paolo IMI, a deal that marked the beginning of the long-overdue consolidation of Italian banking. ${ }^{2}$ This was followed by the merger in 2007 of Italy's two largest banks: Unicredito and Capitalia. This changed approach to banking policy in Italy-based on the opening up of the Italian financial market and banking sector to foreign competitors and 
on the role that the Bank of Italy now plays-helps explain the existence of two policy coalitions. One supported the reform of the Bank of Italy and sought Fazio's removal, while the other defended Fazio's governorship. The coalition advocating change was international and outward-oriented, whereas the domestically based, inward-oriented coalition resisted change-and was defeated.

In May 2006, Draghi abolished a rule that required a bank planning a takeover to notify the central bank before its board approved the project. Draghi has also argued that Italian banks need to adopt better corporate governance rules. For example, the rules that limit shareholders in so-called banche popolari, or mutual banks, to just one vote each, regardless of the size of their stakes, should be reviewed. Abolition of these rules would simplify bank mergers in Italy by making it easier for bidders to outweigh small shareholders.

A second objective-the rationalization of the Bank's structure and its resources-has been pursued by closing down the existing delegations in EU capitals while strengthening the Bank's delegations in the US and Japan. A gradual reduction of personnel, discussed with the trade unions, is scheduled to take place. The Italian Foreign Exchange Office is to be fully integrated into the Bank's structure. Draghi made it clear in his annual remarks in May 2007 that "the aim is to reduce bureaucratic procedures; simplify and rationalize working practices, thus fostering individual responsibility; reallocate resources from the Bank's internal administration to its institutional functions; and tap into new recruitment channels, as with the forthcoming competitive examination for economists, which is open to applicants from abroad."

In addition, the new governor has expressed a positive attitude toward membership of the Eurosystem (the monetary authority of the Eurozone) and has sought to specialize the Bank of Italy on certain specific activities, ${ }^{4}$ whereas Fazio had a reputation as a Euro-skeptic, particularly with regard to the introduction of the euro. ${ }^{5}$ Draghi's international perspective and his experience in dealing with financial markets came to the forefront in his 2007 annual remarks. On that occasion, the governor stressed the potential as well as the risks posed by derivatives instruments, which "can became a source of instability, if intermediaries use them not to hedge existing risks but to increase the volume of risks they assume. In addition, credit derivatives can modify the modus operandi of the banks that use them." to be a timely warning in view of the international financial turmoil that came to pass in the summer and autumn of 2007.

Lastly, the style of the governorship has changed. For example, when the annual report of the Bank of Italy (the Considerazioni Finali, the most important public document produced by the Bank) was published 
at the end of May 2006, the speech delivered by Draghi was approximately one-third shorter than the previous year's speech by Fazio, and it was less emphatic. ${ }^{7}$ In the new management style, there has also been deliberate emphasis on accountability and transparency, as demonstrated by some of the measures discussed above. Moreover, given the fact that Draghi was a former executive at Goldman Sachs, when taking office he announced that he would abstain from any decisions involving his former employer for one year.

It is also important to note that, as discussed by Boitani in this volume, in March 2007, the government proposed a bill for the reform of the regulatory authorities in Italy, including those in the financial sector. The proposed bill envisaged the abolition of the two bodies supervising insurance services and pension funds (ISVAP and COVIP, respectively). Their supervisory tasks and some of their personnel would be transferred to the Bank of Italy, for matters related to prudential supervision, and to the National Commission for Companies and the Stock Exchange (CONSOB), for matters related to the conduct of business. The Bank of Italy would thus be responsible for supervising the entire financial system, whereas CONSOB would be responsible for the conduct of business by all financial operators.

\section{The Content of the Reform of the Bank of Italy}

The changes introduced during Draghi's governorship have been possible due in part to the reform of the Bank of Italy, which was agreed upon in the autumn of 2005 in the wake of a scandal that involved Fazio. The law on savings, which had been in the making since 2002 and was eventually adopted in December 2005, introduced five important amendments to the legislation governing the central bank. ${ }^{8}$

The first change concerned the governance structure of the bank, to be precise, the decision-making process, which was rendered more pluralistic in that all central bank decisions with external implicationswith the exception of those concerning the activities of the European System of Central Banks (ESCB) - are now taken by the five-member Executive Board, not by the governor alone, as had been the case in the past. Moreover, written justifications for the decisions made, especially in the supervisory field, have to be provided by the Bank, and minutes of the meetings of the Executive Board have to be kept.

Before the 2005 reform, the Bank of Italy was one of the most centralized and hierarchical central banks in Europe-a sort of monocratic institution. ${ }^{9}$ Although the Executive Board, which consists of the governor, the director-general, and three deputy directors-general, ${ }^{10}$ 
was established during the governorship of Guido Carli in the 1960s, power continued to be concentrated in the hands of the governor until the 2005 reform. ${ }^{11}$

The second change concerned the procedures for appointing and dismissing the governor and the Executive Board. The goal was to give the government a greater say in the process. Before 2005, the nomination of all four members of the Executive Board, hence also the governor, was proposed by the Consiglio Superiore (Board of Directors) and had to be approved by a decree of the president of the Republic, acting on the proposal of the prime minister together with the treasury minister, after discussion in the Council of Ministers (Article 19 of the Bank's statute). The 2005 reform increased the influence of the government in the appointment procedures in that the governor is now appointed by a presidential decree, acting on the proposal of the prime minister, followed by a deliberation of the Council of Ministers, after having consulted the Consiglio Superiore. In other words, after 2005, the Consiglio Superiore is only consulted-its opinion is not legally binding. The other members of the Executive Board are appointed by the Consiglio, following the proposal of the governor. The appointments must be approved by a presidential decree, acting on the proposal of the prime minister in consultation with the minister for the economy.

The Consiglio Superiore is composed of 13 members and is chaired by the governor. Its members are elected by the holders of the Bank's capital quotas and are appointed for five-year terms, which are renewable twice. They are elected by a secret vote in a process, apparently immune to interference from the government of the day, that generally follows the proposals put forward by the Bank itself. ${ }^{12}$ Giuseppe Guarino describes the Consiglio Superiore as a body that is deeply incorporated into the Bank's tradition, protective of the autonomy enjoyed by the institution and supportive of the general guidelines of the governor. ${ }^{13}$ This became quite apparent in 2005, when the Consiglio was very reluctant to withdraw its support from the governor, who was at the center of a scandal (explained in more detail below).

The third change was the introduction of a fixed-term mandate for the governor and the Executive Board. Before 2005, all four members of the Executive Board were appointed sine die, that is, their mandates was open-ended, and there was no age limit for these positions, which was exceptional among central banks. In practice, since World War II, the longest period for governors to have remained in office was over a decade, as it was for the other members of the Board. The same body that proposed the appointment of the members of the Executive Board, the Consiglio Superiore, could repeal their appointment 
through a joint decision-making procedure that involved the government and the president of the Republic. Since the 2005 reform, each member of the Executive Board has a six-year mandate that can be renewed only once and can be repealed by the government after consultation with the Consiglio.

The fourth change introduced by the law on savings concerned competition policy in the banking sector. The Bank of Italy is responsible for the systemic stability of the financial sector and the prudential supervision of banks and financial intermediaries dealing with securities. CONSOB oversees the Italian securities market and aims to protect the public by ensuring transparency, encouraging the disclosure of information from listed companies (including banks), and monitoring market participants' behavior. Prior to the 2005 reform, the central bank was also in charge of competition policy in the banking sector, and hence mergers and acquisitions were subject to the authorization of the Bank of Italy. ${ }^{14}$ The reform basically left untouched the extensive supervisory powers of the central bank, but the tasks that dealt with banking competition policy were transferred to the Competition Authority, which had been established in 1990 and which is independent of the central bank. Whereas the Bank of Italy would conduct its evaluation of mergers and acquisitions by taking into account "sound and prudent management issues," the Competition Authority would base its assessment on the impact of mergers and acquisitions upon competition (author's translation, Law 262, December 2005).

The fifth modification concerned the ownership structure of the central bank, whereby only the state and public bodies are allowed to hold shares in the bank's capital. Before 2005, and as a consequence of the process of privatization of the banking sector that unfolded in Italy in the 1990s, private banks held a large part of the central bank's shares. This part of the reform is still in the process of being completed.

\section{The Policy-Making Process of the Reform}

The policy-making process of the reform of the Bank of Italy was very time-consuming and resulted in limited changes, when compared to the experience of other central banks and supervisory authorities in the last decade (e.g., in the UK, Germany, Belgium, the Netherlands, Ireland). The changes that were to be introduced were debated by the government and the two parliamentary chambers for approximately three years, going back and forth several times, given the fact that both chambers have the same powers. Eventually, the reform fell short 
of the expectations for an overhaul of the system because no political agreement could be reached, while vetoes prevented attempts to push it through forcibly. Moreover, the central bank managed to fend off efforts to reduce its supervisory powers.

Until the twenty-first century, the Bank of Italy had traditionally been regarded as an effective supervisor, something to which the absence of any significant banking crisis in Italy in the last 20 years or so is testament. Yet the Cirio financial crack in November 2002 and the Parmalat insolvency in December 2003 created tensions between the Bank of Italy and the political authorities, as well as between the central bank and CONSOB, which were both responsible for different aspects of supervision. Although these two insolvencies could hardly be ascribed to systematic supervisory failures, they triggered a heated debate on the configuration and allocation of supervisory responsibilities.

Several legislative proposals were discussed by the executive and by Parliament between 2002 and 2005. The proposal most fervently supported by the treasury minister, Giulio Tremonti, envisaged the creation of an independent supervisory authority external to the central bank, assigning competition policy in the banking system to the Competition Authority. If approved, this proposal would have deprived the central bank of its most important remaining functions, and for this reason the Bank strongly opposed these measures.

The Bank managed to safeguard its prerogatives in this field by deploying its intangible assets, most noticeably its expertise and institutional credibility, by engaging in lobbying activity, and by successfully mobilizing supporters from a cross-section of the political spectrum. ${ }^{15}$ In the end, these changes were not included in the law on savings that was finally adopted in 2005. However, two episodes weakened the institutional credibility of the central bank, undermining its ability to resist changes that were consequently inserted in the law at the eleventh hour. Two important amendments in particular were added: in the first, banking competition policy was assigned to the Competition Authority and, in the second, the governance structure of the central bank was made more pluralistic.

The most publicized cases, which had caught the attention of the whole of Europe, were the two proposed takeovers of Italian banks in 2004-2005: the Spanish group Banca Bilbao Vizcaya Argentaria sought to take over Banca Nazionale del Lavoro (BNL), and ABN Amro proposed to take over Banca Antoniana Popolare Veneta (Antonveneta). In an attempt to stave off these foreign takeover bids, Governor Fazio intervened to endorse counter-bids launched by the Italian banks Banca Popolare di Lodi and Unipol, respectively. Both foreign banks involved in the attempted takeovers complained to the European Commission, 
which had given its authorization on the grounds that the transactions did not jeopardize competition in the banking sector. European Commissioner for Competition Neelie Kroes launched an inquiry into the episodes, while European Commissioner for the Internal Market and Services Charlie McCreevy expressed his concerns in a letter to Governor Fazio in 2005.

The Antonveneta case was subsequently investigated by Italian magistrates, who began to gather evidence of wrongdoing (insider trading and abuse of office) committed by the governor. This intervention by Italian magistrates highlights the centrality of judicial investigation in triggering the reform process, as it broke the grip of the dominant power group, one of the two policy coalitions discussed below. It also emerged that the governor and some close collaborators had overturned the negative opinion submitted by the Supervisory Department of the Bank of Italy, which had refused to authorize Lodi's acquisition of the Antonveneta share. This episode then caused an institutional rift between the central bank's top management and its Supervisory Department. There were, in any case, tensions within the Bank more generally during Fazio's tenure, given the governor's tendency to self-isolation.

The banking system in Italy did not lobby for, or even openly endorse, the reform of the Bank of Italy and the supervisory framework for three reasons. Firstly, the most inward-oriented part of the Italian banking system was comfortable with (and indeed protected by) the "economic patriotism" (or financial protectionism) espoused by Governor Fazio. Moreover, and partly following from this, the limited presence of international market operators, financial conglomerates, and institutional investors in Italy helps to explain the lack of interest in a single supervisory authority for the entire financial sector-a model of financial supervision that has been adopted in several EU countries over the last decade. Secondly, the banking sector in Italy has traditionally been responsive to the policy preferences of the central bank, which, in this case, was directly affected by the reform and thus had strong institutional preferences. Thirdly, despite the Cirio and Parmalat affairs and the scandal involving Fazio, Italian banks were, overall, satisfied with the existing supervisory framework. ${ }^{16}$

Nonetheless, external pressure for change had been mounting in Italy since the start of the decade as an increasing number of foreign financial companies attempted to penetrate Italy's banking sector. Their efforts were backed by the European Commission, which was keen to promote further financial market integration in Europe. These developments strained the existing institutional and policy frameworks in the fields of banking supervision and competition policy. 


\section{The Role of External Factors in the Reform}

The reform undergone by the Bank of Italy cannot be fully understood unless it is placed in a broader comparative context. In particular, three European factors merit attention. First, the establishment of EMU changed the role of the national central banks that are part of the Eurosystem, requiring some adjustments of their structure and functions. Second, and partly following the creation of the single currency, there was a wave of financial integration characterized by cross-border and cross-sectoral financial activities that placed pressure on the existing arrangements for financial services regulation and supervision in Europe, triggering a reform of the framework for financial services supervision in various countries across the EU. Thirdly, there was the activity of the Commission and the ECB, which supported the process of financial market integration and the removal of obstacles to it.

EMU represented a turning point for the national central banks that are members of the Eurosystem. ${ }^{17}$ In the Eurozone countries, monetary policy is no longer set at the national level. Instead, it is set by the Governing Council of the ECB, which comprises the members of the Executive Board in Frankfurt and the governors of the national central banks in the Eurosystem. The exchange rate policy of the euro is also set at the Eurozone level. Ostensibly a shared competence between the ECB and the Council of Economic and Finance Ministers, it is in fact decided by the ECB.

The ECB contributes to the smooth operation of the payments systems, and it established its own system, TARGET 1 (recently upgraded to TARGET 2), for systemically important payments. The ECB is in the process of setting up TARGET 2 securities for the clearing and settlement of securities. The Bank of Italy, the Bundesbank, and the Banque de France were the national central banks that put in motion the creation of TARGET 1 and 2 . They were subsequently joined by the Banco de Espana.

The external representation of the Eurozone is a complex matter. ${ }^{18}$ However, it is important to point out that national central banks, especially the central banks of the G7 and G10 countries, as well as those sitting in the Basel Committee on Banking Supervision, still perform important external representation functions. The ECB has only a minimal role in banking supervision, including prudential supervision, which remains the competence of national supervisory authorities-either central banks or independent supervisory bodies. In this respect, institutional arrangements vary remarkably in the EU and Eurozone, ${ }^{19}$ although all central banks are in charge of, or contribute to, financial stability. 
Broadly speaking, in the Mediterranean countries, such as Spain, Greece, and France, the central banks tend to be in charge of prudential supervision. In the Nordic countries, plus the UK, Germany, and Belgium, after the 1997, 2002, and 2005 reforms, respectively, there is a single financial supervisory authority for the entire financial sector, located outside the central bank. In Ireland and the Netherlands, after the reforms implemented in recent years, the single financial supervisory authority is located in the national central bank (Ireland) or the central bank is the leading component of it (the Netherlands). The new member states have adopted mixed models, with some selecting a single supervisory authority for the entire financial system. It is important to note that the reform of central banks and the reform of the institutional framework for financial supervision are often interlinked and are influenced by the establishment of EMU in two ways: first, through membership of the Eurosystem, which affects the national central banks of the countries that have adopted the euro, and, second, through increased financial market integration, partly deriving from the creation of the single currency, which affects all the member states of the EU.

\section{The Bank of Italy's Adaptation to Membership of the Eurosystem}

Membership of EMU, and hence of the Eurosystem, brought about institutional and policy changes in the central banks of the participating member states. First, the central banks had to be made fully independent, and this was effected in Italy mainly in 1992-1993. In 1992, the Bank of Italy was given the formal right to change interest rates, and in 1993 the Treasury account at the central bank was transformed into an interest-bearing deposit that can only have a positive sign. Second, in 1999, monetary and exchange rate policy decisions were transferred to the Eurozone level, and the national central bank had to undergo some internal restructuring in order to be able to operate in the Eurosystem. Third, central banks, especially in the large countries, had to adapt to a much-reduced role.

The rather paradoxical situation in which the Italian government found itself in 2005 was perhaps the result of the Bank of Italy's excessive political independence, and it is an interesting example of an institutional lock-in caused by a combination of national and EU legislation. According to EU legislation, national governments can dismiss national central bank governors only if they are found guilty of serious misconduct. Moreover, governors are entitled to appeal to the European Court of Justice. According to Italian law before the 2005 
reform, a governor's appointment did not have a time or age limit, and the incumbent could be dismissed only via a cumbersome joint decision-making procedure on the basis of a proposal from the Consiglio Superiore, a body embedded in the Bank. The strong guarantees provided by EU legislation against the unfair dismissal of national central bank governors assume a fixed-term mandate for the governors, as is the case in all the other EU countries (with the exception of Denmark, which does, however, have an age limit), at the end of which the government has the power to renew the mandate or not, as the case may be. A fixed-term mandate did not apply to Italy before the 2005 reform-hence the institutional deadlock. ${ }^{20}$

It is telling that when Minister of the Treasury Domenico Siniscalco resigned in September 2005, following a serious disagreement with Fazio, he wrote a letter to the president of the ECB, Jean-Claude Trichet, raising the issue of the "independence of government from central banks." 21 The previous minister of the treasury, Giulio Tremonti, had resigned in 2004 after falling out with Fazio over an attempt to reduce his powers. Governor Fazio eventually resigned in December 2005 as a result of heavy domestic political pressure from the government, indirect external pressure (exerted mainly through financial markets), and faltering support from within the Bank.

Interestingly, in September 2005 the Italian government was keen to enlist the support of the ECB, not only for its help in drafting national legislation, as prescribed by the Treaty of the European Union, but also in its efforts to topple Governor Fazio, who was at the center of a major controversy after being accused of preventing foreign takeovers. Since the Italian government lacked the legal power and the political will to dismiss the governor, an attempt was made by the Italian government to enlist the direct intervention of the ECB on this matter, with a view to altering the domestic political opportunity structure. The ECB, however, refrained from intervening on the grounds that doing so was not part of its remit.22

The Bank of Italy has approximately 8,000 employees. Under the Fazio governorship (1993-2005) there were no substantial cuts in staff numbers in preparation for or after EMU membership. Indeed, a recurrent criticism is that, having lost the task of setting monetary and exchange rate policies at the national level, the Bank of Italy was overstaffed and yet refused to adapt its structure to its diminished policy competences. However, this approach changed with the appointment of Draghi, and there now are plans in place for a gradual reduction in personnel, as well as an internal reorganization of the Bank.

The establishment of EMU represented the main critical juncture for central banking in Italy. This was due not only to the adaptational 
pressure to adopt specific templates in the national central banking framework, but also to the genuine difficulty of defining a new role for the Bank of Italy, partly because several special functions that it performed had been transferred to other parts of the state apparatus, ${ }^{23}$ and partly because many of its traditional functions had been transferred to the ECB. Some high-caliber officials (often the most outward-oriented ones) left the Bank to take up senior positions in international organizations, at the ECB, at the Treasury, and in private banks. Among the national central bank governors, Fazio was one of the most determined to safeguard the competences of national central banks within the Eurosystem or, to put it another way, to limit the competences and power of the ECB and its Executive Board in Frankfurt. This approach changed after the appointment of the new governor, Draghi.

It should also be noted that during the drafting of the law on savings, which amended central banking legislation, the Italian government requested the ECB's legal opinion three times (May 2004, October 2005, and December 2005). In its opinion issued in October 2005, following the revelations of the Fazio affair, the ECB proposed introducing the principle of collegiality for the Executive Board's decision-making on measures related to non-ESCB tasks-first and foremost, supervisory issues - and the introduction of a term mandate, renewable once, for all members of the Executive Board. These suggestions were eventually incorporated into the relevant legislation in December 2005. The ECB also repeatedly highlighted the need to ensure that the planned transfer of the Bank of Italy's share capital to the state was compatible with the provisions of the Treaty of the European Union concerning the avoidance of monetary financing and the need for sound fiscal policy.

\section{Conclusion}

This chapter has described and discussed the first tangible results stemming from the new management and revised structure of the Bank of Italy. In particular, it has examined the 2005 reform of the Bank of Italy, which laid the groundwork for the major banking mergers of 2007. It argues that the main drivers of the reform were external (European) factors, namely, EMU and financial market integration, whereas the main obstacles to change were domestic, principally, the configuration of the Italian financial system and domestic politics. These structural factors generated two opposite policy coalitions. On the "external" side, there were EU bodies, the European Commission and the ECB, 
which were keen to promote the process of financial market integration and the effective functioning of the Eurosystem; some foreign governments (especially those hosting large financial groups in their territory); transnational financial groups eager to enter the Italian market; and foreign media, especially the Anglo-Saxon press (the Financial Times published several critical articles on this topic). All of these forces pushed for a reform of the banking supervisory framework in Italy and criticized the behavior of the central bank with regard to competition policy, as well as the Fazio governorship more generally. With the exception of the ECB, they were not primarily concerned with the internal governance structure of the Bank of Italy.

On the "domestic" side, the second policy coalition brought together a cross-section of political forces and domestic financial market players who sought to maintain the status quo and to "defend" the Bank of Italy for a variety of reasons, including its institutional prestige, the importance of protecting its independence from political elites, and the political calculus and economic return deriving from its protectionist stance and, allegedly, from specific decisions made by Governor Fazio. Some of those who supported non-reform or minimal reform did so because it was difficult to find a credible alternative or agreement that would satisfy the disparate interests and policy preferences of the main players.

Last but not least, the Bank itself-first and foremost, its incumbent top management-opposed the reform. Even outside the circle of senior officials close to the governor, three considerations encouraged caution: the importance of safeguarding the Bank's independence; the desire to overcome the existing impasse before the governor resigned; and, finally, the need to avoid tarnishing, and ideally the opportunity to restore, the Bank's credibility.

It is also important to note that, unlike in monetary policy, where there is a broad consensus on central bank independence, in the supervisory field a variety of different models exists in Europe and worldwide, with no agreement as to the "best model."24 Moreover, unlike in monetary policy, in EMU there are few binding EU (or EMU) institutional and policy templates concerning banking supervision and competition policy. Hence, there is no direct adaptational pressure on national supervisory frameworks of the member states that are part of the Eurozone.

The 2005 reform of the Bank of Italy has been partly an indirect, delayed response to the establishment of EMU. Adaptation to membership of the ESCB has been relatively difficult for the Bank of Italy, especially among the top-level management, as was the case with Governor Fazio and some of his closer advisers. In terms of personnel 
employed and internal organizational structures, no major restructuring took place after joining EMU until 2005.

This delayed response can in part be ascribed to institutional features, such as the persistent weakness and fragmentation of the country's domestic political institutions, the enduring strength of the central bank (which is still one of the most trusted institutions in Italy), and the constitutional central bank independence embedded in the "ECB model," with a distinctive Italian variation (a governor appointed for life, largely through an internal process). Finally, the delayed adaptation of the central bank in Italy was also the result of Governor Fazio's approach to banking policy, which tended toward Euro-skepticism, since before the 2005 reform he had unchecked power within the Bank and considerable influence within Italy.

\section{Notes}

1. The new rules increased the number of members of the Executive Board from four to five, to avoid the possibility of a tie.

2. In 2006, Banca Intesa considered a merger with Capitalia, but the transaction collapsed amid wrangling between the banks' two executives.

3. M. Draghi, Considerazioni Finali [Annual Remarks], 31 May 2007.

4. One should also mention the promotion of women's interests, both in practice (several women were appointed to senior positions) and in the governor's speeches (e.g., encouraging the return to work after maternity leave, flexible working arrangements, etc.).

5. L. Quaglia, "Italy's Policy towards European Monetary Integration: Bringing Ideas Back In?” Journal of European Public Policy 11 (2004): 1096-1111.

6. M. Draghi, Considerazioni Finali, 31 May 2007.

7. M. Draghi, Considerazioni Finali, 31 May 2006.

8. On the Bank of Italy before the reform, see M. Arcelli, ed., Il Ruolo della Banca Centrale nella Politica Economica (Bologna: Il Mulino, 1992); A. Finocchiaro and A. Contessa, La Banca d'Italia e i Problemi della Moneta e del Credito (Rome: Bancaria, 2002); L. Quaglia, "An Integrative Approach to the Politics of Central Bank Independence: Lessons from Britain, Germany and Italy,” West European Politics 28 (2005): 549-568; L. Quaglia, "Civil Servants, Economic Policies and Economic Ideas: Lessons from Italy,” Governance 18 (2005): 545-566.

9. Two of the people interviewed likened this system to the papacy. A third person interviewed emphasized the importance of the internal hierarchy by comparing it to a military structure.

10. The number of deputy directors-general was raised from two to three in 2006, so as to have an odd number of members of the Executive Board.

11. G. Guarino, "Il ruolo della Banca d'Italia," in L'Autonomia delle Banche Centrali, ed. D. Masciandaro and S. Ristuccia (Milan: Ed. Comunità, 1988), 281-301. 
12. Interviews carried out by the author in Rome, March 2002.

13. Guarino, "Il ruolo della Banca d'Italia," 281-301.

14. Any acquisition of a controlling stake in an Italian bank and ownership of more than 5 percent of the shares of any Italian bank were subject to the authorization of the Bank of Italy.

15. Interviews carried out by the author in Rome, June 2006.

16. As one of them put it in an interview, bankers generally felt safer with the Bank of Italy taking care of banking supervision than with alternative institutional arrangements. Interviews carried out by the author in Rome, June 2006.

17. On the ECB, see L. Bini Smaghi and D. Gros, Open Issues in Central Banking (London: Macmillan, 1999); D. Howarth and P. Loedel, The European Central Bank (Basingstoke, UK: Palgrave, 2005); H. Scheller, The European Central Bank (Frankfurt: European Central Bank, 2004).

18. T. Padoa-Schioppa, The Euro and Its Central Bank (London: MIT Press, 2004).

19. D. Masciandaro, ed., Handbook of Central Banking and Financial Authorities in Europe (Cheltenham, UK: Edward Elgar, 2005).

20. L. Quaglia, Central Banking Governance in the European Union: A Comparative Analysis (London: Routledge, 2008).

21. Financial Times, 22 September 2005.

22. Quaglia, Central Banking Governance, 103.

23. L. Quaglia, "Civil Servants, Economic Policies and Economic Ideas: Lessons from Italy," Governance 18 (2005): 545-566.

24. A. Busch, "National Filters: Europeanisation, Institutions, and Discourse in the Case of Banking Regulation," West European Politics 27 (2004): 310-333. 